Original Article

\title{
Anticonvulsant effects of desvenlafaxine on modulating brain monoamine and oxidative stress in mice
}

\author{
Efeitos anticonvulsivantes da desvenlafaxina na modulação da monoamina cerebral e \\ do estresse oxidativo em camundongos
}

Khalid Saad Alharbi ${ }^{*}$ (1)

${ }^{1}$ Department of Pharmacology, College of Pharmacy, Jouf University, Sakaka, Aljouf, 72341, Saudi Arabia

\begin{abstract}
Desvenlafaxine succinate (DVS) inhibits serotonin reuptake selectively and is approved for major depressive disorders. This research investigated influence of DVS on modulating brain monoamine and oxidative stress in mice. The antiepileptic potential of DVS (10,20, or $30 \mathrm{mg} / \mathrm{kg} /$ i.p.) in pentylenetetrazole (PTZ; $85 \mathrm{mg} / \mathrm{kg}$ ) with i.p. route of administration, strychnine (STR; $75 \mathrm{mg} / \mathrm{kg}$ ) with i.p. route, pilocarpine ( $400 \mathrm{mg} / \mathrm{kg}$ ) with s.c. route and maximal electroshock MES-induced convulsion in mouse models. The activities of oxidative stress, i.e. superoxide dismutase (SOD), glutathione (GSH) and lipid peroxidation (LPO) as well as gamma-aminobutyric acid (GABA) in the brains of PTZ-induced convulsive mice. Treatment with DVS increased the latency to develop siezures and declined mortalities in rodents against PTZ, STR and pilocarpine-induced convulsions. Results of MES-leaded siezures revealed that DVS reduced tonic hind limb extension duration and mortalities significantly. Brain, SOD, GSH and GABA level were significantly $(\mathrm{P}<0.01)$ increased and LPO reduced significantly $(\mathrm{P}<0.01)$ after DVS treatment. Furthermore, the DVS did not show any motor coordination signs in the rotarod test. We demonstrated that the role of DVS in convulsion genesis in mice under control condition and attenuate the PTZ-induced oxidative damage.
\end{abstract}

Keywords: anticonvulsant effect, Desvenlafaxine, oxidative stress, Pentylenetetrazol.

\begin{abstract}
Resumo
O succinato de desvenlafaxina (DVS) inibe seletivamente a recaptação da serotonina e é aprovado para transtornos depressivos maiores. Esta pesquisa investigou a influência do DVS na modulação da monoamina cerebral e do estresse oxidativo em camundongos. O potencial antiepiléptico de DVS (10, 20 ou $30 \mathrm{mg} / \mathrm{kg}$ / i.p.) Em pentilenotetrazole (PTZ; 85 mg / kg) com i.p. via de administração, estricnina (STR; 75 mg / kg) com i.p. via, pilocarpina (400 mg ( kg) com s.c. rota e convulsão induzida por MES de eletrochoque máximo em modelos de camundongos. As atividades de estresse oxidativo, ou seja, superóxido dismutase (SOD), glutationa (GSH) e peroxidação lipídica (LPO), bem como ácido gama-aminobutírico (GABA) nos cérebros de camundongos convulsivos induzidos por PTZ. O tratamento com DVS aumentou a latência para desenvolver crises e diminuiu a mortalidade em roedores contra convulsões induzidas por PTZ, STR e pilocarpina. Os resultados de siezures conduzidos por MES revelaram que o DVS reduziu significativamente a duração e a mortalidade da extensão tônica dos membros posteriores. Os níveis de cérebro, SOD, GSH e GABA aumentaram significativamente $(\mathrm{P}<0,01)$ e o LPO reduziu significativamente $(P<0,01)$ após o tratamento com DVS. Além disso, o DVS não apresentou sinais de coordenação motora no teste do rotarod. Demonstramos o papel do DVS na gênese da convulsão em camundongos sob condição de controle e atenua o dano oxidativo induzido por PTZ.
\end{abstract}

Palavras-chave: efeito anticonvulsivante, Desvenlafaxina, estresse oxidativo, Pentilenotetrazol.

\section{Introduction}

DVS is approved for management depression, chemically unrelated to other existing options (tricyclics/tetracyclic, dual-acting reuptake inhibitor of serotonin-norepinephrine (SNRI) (Solem et al., 2016). Preclinically DVS found to inhibit reuptake of serotonin (5-HT), norepinephrine (NE) and weakly dopamine (DA). DVS is relatively more potent inhibitor of norepinephrine transporter (NET) than pure venlafaxine findings at testifies its less potent actions on
NET than on the serotonin reuptake pumps (Asokan et al., 2014, Santos Junior et al., 2002). DVS is an atypical antidepressant which is used in neurological illnesses, blocks transporter proteins especially for neurotransmitters affecting mood, hence, increase neurochemicals (5-HT and NE) at synaptic space. Roughly it is inhibits 5-HT reuptake ten times more affinity than norepinephrine (Deecher et al., 2006).

*e-mail: kssalharbi@ju.edu.sa

Received: December 3, 2020 - Accepted: March 15, 2021 
Depression co-exists with epileptic disorder often, considerably found responsible for suicide tendencies in epileptic patients. Researchers have already claimed that proper antidepressant medications improve the outcome of both disorders (Cardamone et al., 2013). The antidepressants inhibit reuptake of NE and 5-HT presynaptic nerve terminals, investigators endorsed both the antidepressant and convulsant liabilities to these same pharmacodynamic responses (Fasipe, 2018). Finally, it has been reported that selective reuptake inhibitors of serotonin (SSRI) and norepinephrine/ serotonin reuptake inhibitors (SNRI) reveal the least proseizure activity and suggested as choice of drugs in patients with depression and epilepsy as co-morbidity (Cardamone et al., 2013). Nemrous experimental findings established noradrenergic and serotonergic agonism results antidepressant and anticonvulsant effects (Blier and El Mansari, 2013). 5-HT-like NE exhibits antiseizure character in most convulsion models of rodents (Tupal and Faingold, 2019; Nayana, 2014). Present study intended to explore an innovative strategy to intensify the usefulness of anticonvulsant therapy and to find/indicate antidepressants in the treatment of epilepsy. It has not been reported yet that either the DVS affects convulsion in mice or not. Hence this protocol designed to evaluate the antiepileptic potential of DVS using different paradigm in mice.

\section{Materials and Methods}

\subsection{Animals}

Male healthy albino mice of 6-7 weeks were selected \& housed under maintained standard ecological conditions. The animals had unrestricted access to a normal pellet diet and water ad libitum. The animal study was permitted by Local bioethics committee of Jouf University, Sakakah, Saudi Arab. Experimental rodents were ingenuous to drug treatments at the start of the study. Animals shifted to the experimental area with home cages and acclimatized to this new environmental condition for one hour before conducting experiments. Testing done in a counter-balanced directive concerning the experiments in a noise-free area.

\subsection{Drugs and Chemicals}

DVS, pentylenetetrazole (PTZ), strychnine (STR) and pilocarpine (Sigma-Aldrich Co, St. Louis, MO, USA).

\subsection{PTZ-, STR-, and pilocarpine-induced convulsion models}

Experimental animals administered DVS $(10,20$, or 30 $\mathrm{mg} / \mathrm{kg}$, i.p.) 30 minutes before to the exposure of PTZ (85 $\mathrm{mg} / \mathrm{kg} /$ i.p.) (Azimi and Asgarpanah, 2021), STR (75 mg/ $\mathrm{kg} / \mathrm{i} . \mathrm{p}$.), and pilocarpine (400 $\mathrm{mg} / \mathrm{kg}$, subcutaneously). Animals then replaced back to their home cages and observed for next $30 \mathrm{~min}$. Latency to first seizure, \% animals demonstrating convulsions, latency in mortalities, and \% of deaths were recorded (Wlaź et al., 2015, Dighe and Barve, 2019). Animals those did not show any tonic or clonic convulsion within 30 mins duration of PTZ, STR and pilocarpine exposure reported as protected. Control group administered with saline instead of DVS.

\subsection{Maximal electroshock (MES)-induced convulsion}

Rodents selected randomly and divided into four groups ( $n=6)$, administered either saline or DVS $(10,20$ or $30 \mathrm{mg} / \mathrm{kg}$, i.p.). The electric current stimulus ( $18 \mathrm{~mA}, 50 \mathrm{~Hz}$ for $0.2 \mathrm{~s}$ ) after $30 \mathrm{~min}$ using an electroconvulsometer by corneal electrodes. Proportion protection and hind limb extension time (i.e., hind limbs outstretched at $180^{\circ}$ to their body axis) noted. $100 \%$ protection considered as absolute lack of hind limb extension (Viswanatha et al., 2016).

\subsection{Rota rod test}

Ataxia in mice was assessed employing the rotarod test. Animals located diameter on a $6 \mathrm{~cm}$ rod rotating at $25 \mathrm{rpm}$, (height $25 \mathrm{~cm}$ from the floor). Mice grouped into 4 sets ( $n=6)$ and educated to stay on the rod for 3 sequential trials ( $1 \mathrm{~min} /$ trial). Subsequent day, animals of each set administered either saline or DVS (10, 20 or $30 \mathrm{mg} / \mathrm{kg}$, i.p.). 30 min later, every single mice positioned on rotating rod for $1 \mathrm{~min}$. \% of animals presenting motor incordination calculated (Tirumalasetti et al., 2015).

\subsection{Estimation of brain GABA (gamma-Aminobutyric acid) in PTZ-induced mice}

After sacrificing animals, brain was isolated instantaneously. The assessment of brain GABA levels done according to formerly described procedures (Herrera-Calderon et al., 2018a).

\subsection{Estimation of oxidative stress parameters in PTZ- induced mice}

The extent of LPO measured as malondialdehyde (MDA) content in the tissue, SOD and GSH valued in the brain tissue, conferring to earlier stated approaches (HerreraCalderon et al., 2018a, Reddy et al., 2018, Noor et al., 2015).

\subsection{Statistical analysis}

Results are shown as means \pm standard error of the mean. All the other variables were scrutinized by one way ANOVA tracked by a post hoc test (Dunnett's). $P<0.05$ were considered as significant. GraphPad used for statistical calculations (Prism Software).

\section{Results}

\subsection{PTZ-, STR-, and pilocarpine-induced convulsion}

Treatment of DVS significantly $(P<0.01)$ affected the PTZinduced convulsions (Table 1); STR-induced convulsions (Table 2) and pilocarpine-induced convulsions in mice (Table 3), respectively. Statistical analysis (Dunnett's post hoc test) results claims that DVS administration (10,20 or $30 \mathrm{mg} / \mathrm{kg}$, i.p. ) significantly $(P<0.01)$ amplified latencies to develop convulsion and duration of myoclonic seizure as compared to control group. DVS exhibited noteworthy defense against mortality as well as tremors.

\subsection{MES-induced convulsions test}

DVS treatment considerably $(P<0.01)$ affected MESinduced seizures in mice. Statistical analysis depicted that 
Table 1. Effects of DVS on PTZ-induced convulsion.

\begin{tabular}{cccccc}
\hline Group & Dose (mg/kg, i.p.) & $\begin{array}{c}\text { Latency for } \\
\text { convulsion (sec) }\end{array}$ & $\begin{array}{c}\text { Duration of } \\
\text { myoclonic jerks (sec) }\end{array}$ & $\begin{array}{c}\text { \% protection } \\
\text { against seizures }\end{array}$ & $\begin{array}{c}\text { \% protection } \\
\text { against mortality }\end{array}$ \\
\hline Control & $10 \mathrm{ml}$ & $118.3 \pm 7.5$ & $12.5 \pm 1.2$ & 0 & 0 \\
DVS & 10 & $182.2 \pm 8.8$ & $21.5 \pm 0.7$ & 58.2 & 60 \\
& 20 & $244.8 \pm 18.7^{*}$ & $25.6 \pm 0.9^{*}$ & 76.8 & 78 \\
& 30 & $269.7 \pm 17.1^{*}$ & $29.8 \pm 0.4^{*}$ & 80.3 & 80 \\
\hline
\end{tabular}

DVS-desvenlafaxine, PTZ- pentylenetetrazole; mean \pm SEM; ${ }^{*} P<0.01$ vs. saline treatment (Analyzed by post hoc test)

Table 2. Effects of DVS on STR-induced convulsion.

\begin{tabular}{cccccc}
\hline Group & Dose (mg/kg, i.p.) & $\begin{array}{c}\text { Latency for } \\
\text { convulsion }(\mathbf{s e c})\end{array}$ & $\begin{array}{c}\text { Duration of } \\
\text { myoclonic jerks (sec) }\end{array}$ & $\begin{array}{c}\text { \% protection } \\
\text { against seizures }\end{array}$ & $\begin{array}{c}\text { \% protection } \\
\text { against mortality }\end{array}$ \\
\hline Control & $10 \mathrm{ml}$ & $25.5 \pm 3.0$ & $12.50 \pm 1.1$ & 0 & 0 \\
DVS & 10 & $45.5 \pm 3.5$ & $18.50 \pm 1.3$ & 34.0 & 35.9 \\
& 20 & $54.5 \pm 4.4^{*}$ & $20.49 \pm 2.4^{*}$ & 47.5 & 46.0 \\
& 30 & $80.6 \pm 5.6^{*}$ & $25.83 \pm 2.6^{*}$ & 55.9 & 58.7 \\
\hline
\end{tabular}

DVS-desvenlafaxine, STR- strychnine; mean \pm SEM; ${ }^{P} P<0.01$ vs. saline treatment (Analyzed by post hoc test).

Table 3. Effects of DVS on pilocarpine - induced seizures.

\begin{tabular}{cccccc}
\hline Group & Dose (mg/kg, i.p.) & $\begin{array}{c}\text { Latency for } \\
\text { convulsion }(\mathbf{s e c})\end{array}$ & $\begin{array}{c}\text { Duration of } \\
\text { myoclonic jerks (sec) }\end{array}$ & $\begin{array}{c}\text { \% protection } \\
\text { against seizures }\end{array}$ & $\begin{array}{c}\text { \% protection } \\
\text { against mortality }\end{array}$ \\
\hline Control & $10 \mathrm{ml}$ & $410.3 \pm 44.9$ & $15.50 \pm 1.2$ & 0 & 0 \\
DVS & 10 & $716.8 \pm 29.6$ & $19.50 \pm 0.7$ & 51.2 & 59.9 \\
& 20 & $844.0 \pm 59.5$ & $22.66 \pm 0.9^{*}$ & 60.5 & 68.5 \\
& 30 & $1040.0 \pm 45.4^{*}$ & $24.83 \pm 0.4^{*}$ & 69.7 & 71.2 \\
\hline
\end{tabular}

DVS-desvenlafaxine; mean $\pm \mathrm{SEM}$; ${ }^{*}<<0.01$ vs. saline treatment (Analyzed by post hoc test).

Table 4. Effects of DVS on MES-induced seizures.

\begin{tabular}{ccccc}
\hline Group & Dose (mg/kg, i.p.) & $\begin{array}{c}\text { Duration of hind limb } \\
\text { extension }(\mathbf{s e c})\end{array}$ & $\begin{array}{c}\text { \% protection against } \\
\text { seizures }\end{array}$ & $\begin{array}{c}\text { \% protection against } \\
\text { mortality }\end{array}$ \\
\hline Control & $10 \mathrm{ml}$ & $10.3 \pm 1.1$ & 0 & 0 \\
DVS & 10 & $5.8 \pm 0.4$ & 50.0 & 63.1 \\
& 20 & $3.0 \pm 0.5^{*}$ & 67.5 & 83.3 \\
& 30 & $0.8 \pm 0.3^{*}$ & 91.3 & 98.6 \\
\hline
\end{tabular}

DVS-desvenlafaxine, MES- maximal electroshock; mean \pm SEM; ${ }^{*} P<0.01$ vs. saline treatment (Analyzed by post hoc test).

DVS (10, 20 or $30 \mathrm{mg} / \mathrm{kg}$, i.p.) considerably $(P<0.01)$ declined the time spent during hindlimb extension as compared to the normal control animals (Table 4). DVS exhibited significant protection against mortality and convulsions.

\subsection{Rotarod test}

Statistical assessments point out that DVS administration $(10,20$ or $30 \mathrm{mg} / \mathrm{kg}$, i.p.) did not cause any motor incoordination in rotarod study.

\subsection{Effect of DVS on brain GABA level}

The brain inhibitory neurotransmitter (GABA) levels were considerably $(P<0.01)$ and dose-dependently elevated by DVS (10, 20 or $30 \mathrm{mg} / \mathrm{kg}$, i.p.) usage as compared to PTZ control group (Table 5).
Table 5. Effects of DVS on PTZ-induced convulsion in brain GABA in mice.

\begin{tabular}{ccc}
\hline Group & $\begin{array}{c}\text { Dose } \\
\text { (mg/kg, i.p.) }\end{array}$ & $\begin{array}{c}\text { GABA } \\
\text { (ng/g of brain tissue) }\end{array}$ \\
\hline Control & $10 \mathrm{ml}$ & $17.5 \pm 1.0$ \\
DVS & 10 & $22.4 \pm 0.5^{*}$ \\
& 20 & $31.5 \pm 0.5^{* *}$ \\
& 30 & $48.3 \pm 0.5^{* *}$ \\
\hline
\end{tabular}

DVS-desvenlafaxine, GABA-gamma-Aminobutyric acid; Mean \pm SEM; ${ }^{*} P<0.01 ;{ }^{* *} P<0.001$ vs. saline treatment (Analyzed by post hoc test).

\subsection{Effect of DVS on oxidative stress}

The MDA levels significantly elevated in PTZ-induced convulsive mices (Table 6). However, MDA levels found 
Table 6. Effects of DVS on PTZ-induced alteration in oxidative stress in mice.

\begin{tabular}{ccccc}
\hline Group & Dose $(\mathbf{m g} / \mathbf{k g}, \mathbf{i . p .})$ & MDA (nmol/g of brain tissue) & SOD (U/mg of protein) & GSH ( $\boldsymbol{\mu g} / \mathbf{m g}$ of $\mathbf{~ p r o t e i n )}$ \\
\hline Control & $10 \mathrm{ml}$ & $2.3 \pm 1.0$ & $3.40 \pm 0.4$ & $0.80 \pm 0.05$ \\
DVS & 10 & $1.7 \pm 0.5^{*}$ & $7.80 \pm 0.5^{*}$ & $2.15 \pm 0.3^{*}$ \\
& 20 & $1.5 \pm 0.5^{* *}$ & $10.20 \pm 0.7^{* *}$ & $2.68 \pm 0.3^{* *}$ \\
& 30 & $1.2 \pm 0.5^{* *}$ & $10.90 \pm 0.7^{* *}$ & $2.78 \pm 0.2^{* *}$ \\
\hline
\end{tabular}

DVS-desvenlafaxine, MDA-Malondialdehyde, SOD-Superoxide dismutase, GSH-Glutathione; Mean \pm SEM; ${ }^{*} P<0.01 ;{ }^{* *} P<0.001$ vs. saline treatment (Analyzed by post hoc test).

declined $(P<0.01)$ in DVS exposed animals at different dose levels (10, 20 and $30 \mathrm{mg} / \mathrm{kg})$ and PTZ control group. In PTZ control animals were considerably $(P<0.01)$ reduced SOD and GSH actions. While treatment with DVS caused noticeably $(P<0.01)$ and increments dose-dependent in SOD and GSH levels compared to PTZ control mice group.

\section{Discussion}

Present scientific findings report first the anticonvulsant effect of DVS in experimental animal models. By these observations, we conclude that DVS exhibit anticonvulsant action against PTZ, STR and pilocarpine-induced convulsions. Further, DVS administration to the rodents did no cause any sign of motor in-cordination.

DVS may be effective in treating epilepsy-associated serotonin and noradrenaline reuptake inhibitor (Kumar et al., 2016). Depression in epileptic pateints fundamentally differs than common depressive disroders. Drugs targeting serotonin at synapse (SSRIs) are most recommended antidepressants in epileptic patients. The previous study highlighted that SSRIs might have antiepileptic effects in animal induced epilepsy models (Kanner, 2016).

Present study intended to investigate DVS using convulsions paradigm viz., MES, PTZ, STR and pilocarpineinduced mice. Results of MES-induced convulsion paradigm exhibited that DVS dose-dependently reduced the tonic convulsions interval (hind limb extension).

Although, anticonvulsant mechanism action of DVS against MES induced epilepsies is not clear. In the PTZinduced convulsion experiment, DVS dose-dependently increased latencies to produce convulsions as well as duration to myoclonic jerks, suggesting a protective effect. DVS reduce serotonin level at synapse, reserved pentylenetetrazole-induced fits. This finding indicate that there may be other mechanisms that offer antiepileptic effect of antidepressant drugs (Heydari and Davoudi, 2017). DVS had no effect on motor coordination also.

Pilocarpine muscarinic receptor agonist, these receptors predominantly found in the hippocampus, striatum, and cortex. Pilocarpine administration leads to recurring limbic convulsions and status epilepticus, replicating some features of human temporal lobe epilepsy in rodents (Borges Fernandes et al., 2012). Results of current experiments advocates that DVS administration prevent pilocarpineinduced tremors, indicating that DVS antagonize muscarinic receptors in mice brain (Deecher et al., 2006). Earlier findings showed protective effect in the hippocampus and improved after dexmedetomidine on pilocarpine-induced status epilepticus (Tan et al., 2019).

STR-induced convulsions involve blocking of mainly glycine response at spinal cord. Glycine functions as inhibitory neurochemical and STR cause selective antagonism of all glycine receptors (Nakahata et al., 2017). Findings of our experiments revealed that STRinduced convulsions are moderately suppressed by DVS administration.

GABA a universal inhibitory neurochemical plays a vivacious role in numerous neurological disorders, together with a seizures (Kim and Yoon, 2017). It has been documented earlier that the SSRIs has slight impact on GABAergic conduction in the brain (Walia and Gilhotra, 2017). The present research investigated the antiepileptic potential of DVS using different animal models and behavioral and biochemical considerations against PTZinduced convulsions. Results of this research demonstrated that DVS significantly attenuated the alterations in GABA levels and free radical scavenging enzymes in PTZ-induced mice.

In the present study, pretreatment with DVS showed significantly increased latencies for convulsion and duration of myoclonic jerks which may be due to increasing GABA levels. These findings suggest that DVS may have an effect on the GABA receptor, which shows the anti-convulsion potential.

The DVS against MDA levels might be related to the antiseizure activity, MDA measurements describes the level of LPO. Increased oxidative free radicals and dysfunctional mitochondria served as important contributing factors in the development of epilepsies as well as many other neurological diseases (Faghihi and Mohammadi, 2017). Results of our experiments depicted that MDA was considerably elevated following convulsions in mice and DVS showed considerable safety against lipid peroxidation (MDA). It is well documented that LPO cause destruction of biological membranes and affect the function as well (Herrera-Calderon et al., 2018b).

Results of our present research depicted that DVS treatment to animals significantly increased brain SOD and GSH levels. Earlier scientific reports suggested correlation in convulsion and elevated oxidative free radicals (PearsonSmith and Patel, 2017, Geronzi et al., 2018). Some others documented that decreased SOD can lead in neuronal damage (Wang et al., 2018). The reduced SOD levels in PTZ-induced seizures normalized by the dose-dependent manner of DVS. To be attested our findings, a previous 
research documented protective effect of DVS on SOD level in mice (Silva et al., 2016). As mentioned earlier SOD is a potent scavenger of toxic $\mathrm{O} 2$ free radicals that converted to hydrogen peroxide (H2O2) (Mukherjee et al., 2017, Adil et al., 2016). The next step in this cascade of reaction encompasses one more essential antioxidant "GSH". Scientists have reported already that PTZ administration significantly reduces GSH levels (Erkec et al., 2018, AbdelSalam et al., 2019). Findings of our experimental protocol depicted DVS at dose-dependent manner significantly elevated brain GSH levels in PTZ-treated mice. Findings of our experiments interprets that DVS possess anticonvulsant activity by preventing serotonergic and/or noradrenergic mechanisms in convulsion activity.

\section{Conclusion}

The present study revealed that administration of DVS exhibit concentration dependant anticonvulsant activity in experimental animals. These findings support the hypothesis that DVS play a role in inhibition of convulsions in mice under control condition and attenuate the convulsion-induced oxidative damage.

\section{References}

ABDEL-SALAM, O.M., SLEEM, A.A., SAYED, M.A.E.-B.M., YOUNESS, E.R. and SHAFFIE, N., 2019. Neuroprotective effects of low dose anandamide in pentylenetetrazole-induced kindling in rats. Biomedical \& Pharmacology Journal, vol. 12, no. 1, pp. 25-40. http://dx.doi.org/10.13005/bpj/1610.

ADIL, M., KANDHARE, A.D., GHOSH, P. and BODHANKAR, S.L., 2016. Sodium arsenite-induced myocardial bruise in rats: ameliorative effect of naringin via TGF- $\beta /$ Smad and Nrf/HO pathways. Chemico-Biological Interactions, vol. 253, pp. 66-77. http://dx.doi.org/10.1016/j.cbi.2016.05.015. PMid:27174133.

ASOKAN, A., BALL, A.R., LAIRD, C.D., HERMER, L. and ORMEROD, B.K., 2014. Desvenlafaxine may accelerate neuronal maturation in the dentate gyri of adult male rats. PLoS One, vol. 9, no. 6, pp. e98530. http://dx.doi.org/10.1371/journal.pone.0098530. PMid:24896246.

AZIMI, G. and ASGARPANAH, J., 2021. Chemical composition of Zhumeria majdae essential oil and its effects on the expression of morphine withdrawal syndrome and tolerance to the anticonvulsant effect of morphine on pentylenetetrazoleinduced seizures in mice. Brazilian Journal of Biology $=$ Revista Brasileira de Biologia, vol. 81, no. 4, pp. 881-886. http://dx.doi. org/10.1590/1519-6984.228825. PMid:33053122.

BLIER, P. and EL MANSARI, M., 2013. Serotonin and beyond: therapeutics for major depression. Philosophical Transactions of the Royal Society of London. Series B, Biological Sciences, vol. 368, no. 1615, pp. 20120536. http://dx.doi.org/10.1098/ rstb.2012.0536. PMid:23440470.

BORGES FERNANDES, L.C., CAMPOS CÂMARA, C. and SOTO-BLANCO, B., 2012. Anticonvulsant activity of extracts of Plectranthus barbatus leaves in mice. Evidence-Based Complementary and Alternative Medicine, vol. 2012, pp. 2012. http://dx.doi. org/10.1155/2012/860153. PMid:21716675.

CARDAMONE, L., SALZBERG, M.R., O'BRIEN, T.J. and JONES, N.C., 2013. Antidepressant therapy in epilepsy: can treating the comorbidities affect the underlying disorder? British Journal of Pharmacology, vol. 168, no. 7, pp. 1531-1554. http://dx.doi. org/10.1111/bph.12052. PMid:23146067.

DEECHER, D.C., BEYER, C.E., JOHNSTON, G., BRAY, J., SHAH, S., ABOUGHARBIA, M. and ANDREE, T.H., 2006. Desvenlafaxine succinate: A new serotonin and norepinephrine reuptake inhibitor. The Journal of Pharmacology and Experimental Therapeutics, vol. 318, no. 2, pp. 657-665. http://dx.doi.org/10.1124/jpet.106.103382. PMid:16675639.

DIGHE, A.P. and BARVE, K.H., 2019. Anticonvulsant effect of Sphaeranthus flower extracts in mice. Journal of Ayurveda and Integrative Medicine, vol. 10, no. 1, pp. 38-40. http://dx.doi. org/10.1016/j.jaim.2018.06.008. PMid:30638715.

ERKEC, O.E., ARIHAN, O., KARA, M., KARATAS, E., ERTEN, R., DEMIR, H., MERAL, I., MUKEMRE, M. and OZGOKCE, F., 2018. Effects of Leontice leontopetalum and Bongardia chrysogonum on oxidative stress and neuroprotection in PTZ kindling epilepsy in rats. Cellular and Molecular Biology, vol. 64, no. 15, pp. 71-77. http://dx.doi.org/10.14715/cmb/2017.64.15.12. PMid:30672439.

FAGHIHI, N. and MOHAMMADI, M.T., 2017. Anticonvulsant and antioxidant effects of Pitavastatin Against PentylenetetrazolInduced Kindling in Mice. Advanced Pharmaceutical Bulletin, vol. 7, no. 2, pp. 291-298. http://dx.doi.org/10.15171/apb.2017.035. PMid:28761832.

FASIPE, O., 2018. Neuropharmacological classification of antidepressant agents based on their mechanisms of action. Archives of Medicine and Health Sciences, vol. 6, no. 1, pp. 81-94. http://dx.doi.org/10.4103/amhs.amhs_7_18.

GERONZI, U., LOTTI, F. and GROSSO, S., 2018. Oxidative stress in epilepsy. Expert Review of Neurotherapeutics, vol. 18, no. 5, pp. 427-434. http://dx.doi.org/10.1080/14737175.2018.146541. PMid:29651881.

HERRERA-CALDERON, O., SANTIVÁÑEZ-ACOSTA, R., PARI-OLARTE, B., ENCISO-ROCA, E., CAMPOS MONTES, V.M. and LUIS ARROYO ACEVEDO, J., 2018a. Anticonvulsant effect of ethanolic extract of Cyperus articulatus L. leaves on pentylenetetrazol induced seizure in mice. Journal of Traditional and Complementary Medicine, vol. 8, no. 1, pp. 95-99. http://dx.doi.org/10.1016/j. jtcme.2017.03.001. PMid:29321995.

HERRERA-CALDERON, O., SANTIVÁÑEZ-ACOSTA, R., PARI-OLARTE, B., ENCISO-ROCA, E., MONTES, V.M.C. and ACEVEDO, J.L.A., 2018b. Anticonvulsant effect of ethanolic extract of Cyperus articulatus L. leaves on pentylenetetrazol induced seizure in mice. Journal of Traditional and Complementary Medicine, vol. 8, no. 1, pp. 95-99. http://dx.doi.org/10.1016/j.jtcme.2017.03.001. PMid:29321995.

HEYDARI, A. and DAVOUDI, S., 2017. The effect of sertraline and 8-OH-DPAT on the PTZ_induced seizure threshold: role of the nitrergic system. Seizure, vol. 45, pp. 119-124. http://dx.doi. org/10.1016/j.seizure.2016.12.005. PMid:28012414.

KANNER, A.M., 2016. Most antidepressant drugs are safe for patients with epilepsy at therapeutic doses: A review of the evidence. Epilepsy \& Behavior, vol. 61, pp. 282-286. http://dx.doi. org/10.1016/j.yebeh.2016.03.022. PMid:27236241.

KIM, Y.S. and YOON, B.E., 2017. Altered GABAergic Signaling in Brain Disease at Various Stages of Life. Experimental Neurobiology, vol. 26, no. 3, pp. 122-131. http://dx.doi.org/10.5607/ en.2017.26.3.122. PMid:28680297.

KUMAR, U., MEDEL-MATUS, J.S., REDWINE, H.M., SHIN, D., HENSLER, J.G., SANKAR, R. and MAZARATI, A., 2016. Effects of selective serotonin and norepinephrine reuptake inhibitors on depressive- and impulsive-like behaviors and on monoamine transmission in experimental temporal lobe epilepsy. Epilepsia, 
vol. 57, no. 3, pp. 506-515. http://dx.doi.org/10.1111/epi.13321. PMid:26813337.

MUKHERJEE, A.A., KANDHARE, A.D., ROJATKAR, S.R. and BODHANKAR, S.L., 2017. Ameliorative effects of Artemisia pallens in a murine model of ovalbumin-induced allergic asthma via modulation of biochemical perturbations. Biomedicine and Pharmacotherapy, vol. 94, pp. 880-889. http://dx.doi. org/10.1016/j.biopha.2017.08.017. PMid:28810518.

NAKAHATA, Y., ETO, K., MURAKOSHI, H., WATANABE, M., KURIU, T., HIRATA, H., MOORHOUSE, A.J., ISHIBASHI, H. and NABEKURA, J., 2017. Activation-dependent rapid postsynaptic clustering of glycine receptors in mature spinal cord neurons. eNeuro, vol. 4, no. 1, pp. 4. http://dx.doi.org/10.1523/ENEURO.0194-16.2017. PMid:28197549.

NAYANA, N., 2014. Fluoxetine associated with seizure: A case report. Acta Medica International, vol. 1, pp. 143-145.

NOOR, N.A., MOHAMMED, H.S., KHADRAWY, Y.A., ABOUL EZZ, H.S. and RADWAN, N.M., 2015. Evaluation of the neuroprotective effect of taurine and green tea extract against oxidative stress induced by pilocarpine during status epilepticus. Journal of Basic E'Applied Zoology, vol. 72, pp. 8-15. http://dx.doi.org/10.1016/j. jobaz.2015.02.001.

PEARSON-SMITH, J.N. and PATEL, M., 2017. Metabolic Dysfunction and Oxidative Stress in Epilepsy. International Journal of Molecular Sciences, vol. 18, no. 11, pp. 2365. http://dx.doi.org/10.3390/ ijms18112365. PMid:29117123.

REDDY, A.J., DUBEY, A.K., HANDU, S.S., SHARMA, P., MEDIRATTA, P.K., AHMED, Q.M. and JAIN, S., 2018. Anticonvulsant and Antioxidant Effects of Musa sapientum Stem Extract on Acute and Chronic Experimental Models of Epilepsy. Pharmacognosy Research, vol. 10, no. 1, pp. 49-54. http://dx.doi.org/10.4103/ pr.pr_31_17. PMid:29568187.

SANTOS JUNIOR, J.G., DO MONTE, F.H.M., RUSSI, M., AGUSTINE, P.E. and LANZIOTTI, V.M.N.B., 2002. Proconvulsant effects of high doses of venlafaxine in pentylenetetrazole-convulsive rats. Brazilian Journal of Medical and Biological Research, vol. 35, no. 4, pp. 469-472. http://dx.doi.org/10.1590/S0100879X2002000400010. PMid:11960197.

SILVA, M.C.C., DE SOUSA, C.N.S., GOMES, P.X.L., DE OLIVEIRA, G.V., ARAÚJO, F.Y.R., XIMENES, N.C., DA SILVA, J.C., VASCONCELOS, G.S., LEAL, L.K.A.M., MACÊDO, D. and VASCONCELOS, S.M., 2016. Evidence for protective effect of lipoic acid and desvenlafaxine on oxidative stress in a model depression in mice. Progress in Neuro-Psychopharmacology \& Biological Psychiatry, vol. 64, pp. 142-148. http://dx.doi.org/10.1016/j.pnpbp.2015.08.002. PMid:26265141.

SOLEM, C.T., SHELBAYA, A., WAN, Y., DESHPANDE, C.G., ALVIR, J. and PAPPADOPULOS, E., 2016. Analysis of treatment patterns and persistence on branded and generic medications in major depressive disorder using retrospective claims data. Neuropsychiatric Disease and Treatment, vol. 12, pp. 2755-2764. http://dx.doi.org/10.2147/NDT.S115094. PMid:27822048.

TAN, X., TU, Z., HAN, W., SONG, X., CHENG, L., CHEN, H., TU, S., LI, P., LIU, W. and JIANG, L., 2019. Anticonvulsant and Neuroprotective Effects of Dexmedetomidine on Pilocarpine-Induced Status Epilepticus in Rats Using a Metabolomics Approach. Medical Science Monitor, vol. 25, pp. 2066-2078. http://dx.doi. org/10.12659/MSM.912283. PMid:30892279.

TIRUMALASETTI, J., PATEL, M., SHAIKH, U., HARINI, K. and SHANKAR, J., 2015. Evaluation of skeletal muscle relaxant activity of aqueous extract of Nerium oleander flowers in Albino rats. Indian Journal of Pharmacology, vol. 47, no. 4, pp. 409-413. http://dx.doi.org/10.4103/0253-7613.161265. PMid:26288474.

TUPAL, S. and FAINGOLD, C.L., 2019. Fenfluramine, a serotoninreleasing drug, prevents seizure-induced respiratory arrest and is anticonvulsant in the DBA/1 mouse model of SUDEP. Epilepsia, vol. 60, no. 3, pp. 485-494. http://dx.doi.org/10.1111/ epi.14658. PMid:30719703.

VISWANATHA, G.L., VENKATARANGANNA, M.V., PRASAD, N.B. and ASHOK, G., 2016. Evaluation of anti-epileptic activity of leaf extracts of Punica granatum on experimental models of epilepsy in mice. Journal of Intercultural Ethnopharmacology, vol. 5, no. 4, pp. 415-421. http://dx.doi.org/10.5455/jice.20160904102857. PMid:27757273.

WALIA, V. and GILHOTRA, N., 2017. GABAergic influence in the antidepressant effect of fluoxetine in unstressed and stressed mice. Journal of Applied Pharmaceutical Science, vol. 7, pp. 141-147.

WANG, Y., BRANICKY, R., NOË, A. and HEKIMI, S., 2018. Superoxide dismutases: dual roles in controlling ROS damage and regulating ROS signaling. The Journal of Cell Biology, vol. 217, no. 6, pp. 19151928. http://dx.doi.org/10.1083/jcb.201708007. PMid:29669742.

WLAŹ, P., SOCAŁA, K., NIEOCZYM, D., ŻARNOWSKI, T., ŻARNOWSKA, I., CZUCZWAR, S.J. and GASIOR, M., 2015. Acute anticonvulsant effects of capric acid in seizure tests in mice. Progress in NeuroPsychopharmacology E'Biological Psychiatry, vol. 57, pp. 110-116. http://dx.doi.org/10.1016/j.pnpbp.2014.10.013. PMid:25445478. 